\title{
Mathematics Teacher Performance Based on the Perceptions and Competence of Junior High School Students in Labuhanbatu District
}

\author{
Nur Indah Puspita Sari ${ }^{1}$, Sakinah Ubudiyah Siregar ${ }^{2}$ \\ ${ }^{1,2}$ Mathematics Education Study Program, Universitas Labuhanbatu, Indonesia \\ nurindahpuspitasari01@gmail.com,hafizahsiregar88@gmail.com
}

\begin{abstract}
This study aims to see the strengths and weaknesses of the teacher in the teaching process based on the competence aspects of the mathematics teacher and to describe the situation and state of the teacher's competence when in the learning process in the classroom based on student perceptions associated with the competence of the students themselves. Data processing techniques using data analysis Structural Equation Modeling (SEM). The population of this study were junior high school students in Labuhanbatu. The sampling technique used was proportional random sampling leading to simple random sampling, the number of samples obtained was 219 students. Techniques in the data collection process were carried out by distributing a questionnaire on students' perceptions of the mathematics teacher's performance consisting of 48 questions in the form of a Likert scale.
\end{abstract}

Keywords teacher competence; student competence; structural equation modeling

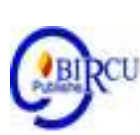

\section{Introduction}

Schools are educational institutions that are both formal, non-formal and informal, which in a school can be carried out by the state or the private sector. The purpose of establishing a school is to provide teaching, manage and educate students through the learning process carried out by educators or teachers (H.Afriansyah, 2019 ).

A teacher is someone whose job and duty is to provide various kinds of knowledge to students or students studying from school, in addition to knowledge, teachers also provide and teach various skills to children or their students. Teacher is a very noble job, both from the perspective of society and the state as well as from a religious point of view. Teachers have an important role in community and state life. The size or level of student achievement is strongly influenced by a teacher (A. Idzhar, 2016). The fields of knowledge that are mastered by a teacher are different, for example, in the field of mathematics or mathematical literacy.

Mathematical literacy can be defined as a person's ability to be able to formulate, apply and interpret mathematics into various contexts, which involves reasoning and using mathematical concepts, procedures, facts, and tools to describe, explain, and relate them in everyday life. Mathematical literacy skills are related to how individuals can apply knowledge in real world problems (real words) everyday, so that the benefits can be felt directly. So it can be said, that mathematical literacy can make it easier for students to find out more about the role of mathematics in everyday life.

Increasing student achievement is strongly influenced by a teacher, however from the student's point of view, in addition to the role of the teacher, the feelings or perceptions of 
a student also affect the quality of student learning achievement (Bashir et al., 2017). Perception is a way for someone to judge their interlocutors in a direct relationship. Based on Slameto's statement (Tarmiji, Basyah, \& Yunus, 2016) that, through perception we can continue to build relationships among humans and to the environment with sensory intermediaries as the intermediary medium which then produces information that can be used to respond. Students' perceptions can be influenced by a teacher's mastery of competencies.

Teacher competence can be seen during the learning process, namely when teachers interact with students (Danim, 2010). In general, students tend to assess their teachers from various aspects such as teacher knowledge of the subject matter, the teacher's ability to communicate, the teacher's ability to select appropriate teaching methods and the teacher's ability to master class. Students play a very important role in the learning process because students 'perceptions can affect students' attitudes towards these subjects. Thus a student's assessment of teacher performance needs to be considered, this perception can be a useful source of information, because it is students who experience, observing and feeling the learning process in the classroom and their evaluation will help to determine whether the teacher has done the learning well and according to standards or not. Students' perceptions of teacher performance can be used to create a fair and objective evaluation system and can help teachers develop and adapt their teaching strategies to increase student understanding and achievement.

Teacher competence and student perceptions are interrelated. Mastery of good teacher competencies will result in good learning which will affect student perceptions (Nuryovi, Wiharna, \& Sriyono, 2017). Especially in mathematics subjects which often get bad perceptions from the student's point of view. Some students have the perception that mathematics is an unpleasant and difficult subject. Because mathematics has many calculations and formulas that require special intellectual talent. Even though mathematics is one of the subjects that form the basis of other sciences and is always studied from elementary to higher education (Palobo \& Nur'aini, 2018). In Etuk's research, Afangideh, and Uya (Etuk, Afangideh, \& Uya, 2013) states that when students 'perceptions of teachers will have a negative effect on students' abilities in learning mathematics. This can cause student mathematics learning outcomes to not achieve learning objectives, and this will raise a criticism of the teacher. Student assessment of teaching carried out by teachers is one form of evaluation of learning and effectiveness carried out by teachers (Ampadu, 2012; Brok, Brekelmans, \& Wubbels, 2006). However, teacher evaluations must consider student needs compared to other things (Sianturi \& Lin, 2016). and it will raise a criticism of the teacher. Student assessment of teaching carried out by teachers is one form of evaluation of learning and effectiveness carried out by teachers (Ampadu, 2012; Brok, Brekelmans, \& Wubbels, 2006). However, teacher evaluations must consider student needs compared to other things (Sianturi \& Lin, 2016). and it will raise a criticism of the teacher. Student assessment of teaching carried out by teachers is one form of evaluation of learning and effectiveness carried out by teachers (Ampadu, 2012; Brok, Brekelmans, \& Wubbels, 2006). However, teacher evaluations must consider student needs compared to other things (Sianturi \& Lin, 2016).

Based on the description that the authors put above, the purpose of this study is to evaluate the performance of mathematics teachers based on the perceptions of students, so that they can find out the strengths and weaknesses of teachers in the teaching process based on aspects of mathematics teacher competence and display information on the relationship between teacher competence and student learning outcomes. In this study, students' perceptions were drawn from student learning outcomes towards mathematics. 


\section{Research Methods}

The research conducted by the author is a quantitative study, in which the research subjects are junior high school students in Labuhanbatu Regency, 2020/2021 academic year with the large number of students participating in this study as many as 219 students.

The instrument that the author uses in this study is a questionnaire that contains indicators of student perceptions regarding pedagogical competence, personality, social and professional competences of teachers as well as student competencies. The number of indicators in this study were 46 indicators, of which 32 indicators were used to measure teacher competence and 14 indicators to measure student competence (Appendix 2).

Techniques in data collection were carried out by distributing questionnaires to students about the performance of mathematics teachers. Data processing using AMOS program. The expected assumptions are as follows:

1. The sample used is large

The number of samples that the author uses in this study is 219 samples, this number is included in the minimum category for large samples. According to Tanujaya (2016), the number of samples used must be greater than the results of multiplying the number of indicators used in the preparation of the instrument, with a minimum of 200 respondents.

2. Multivariate normal distribution data

This normality test is evaluated using the Critical Ratio (CR) value of its skewness and kurtosis. Where the criteria for the $\mathrm{CR}$ value are at -2.58 to 2.58 at a significance level of $1 \%(0.01)$, it can be concluded that the data used are normally distributed both univariate and multivariate. However, these results will not affect the results of the study 3. The expected valid model

The model hypothesized by the author is based on existing theories. With the validity value on the output table standardized regression weight, and the result is that there are no variables with a value below 0.5 , so that the variables that are presented in the model can meet the valid assumption

\section{Results and Discussion}

The results of the normality test using AMOS version 22 software showed that the CR value was outside of -2.58 to 2.58 , so it could be concluded that the data did not meet the multivariate normal assumptions (Appendix 1). The analysis was then continued by observing the loading factor value. Based on the initial model output, several indicators (variables) were still found that had a loading factor value $<0.5$, so that these indicators would be removed / removed from the data. Then the data is analyzed again and the results of Model 2 are obtained in Figure 1. Based on the results in Figure 1, it can be seen that the loading factor value $<0.5$ is no longer found, so it can be concluded that the indicators used in the study are valid. 


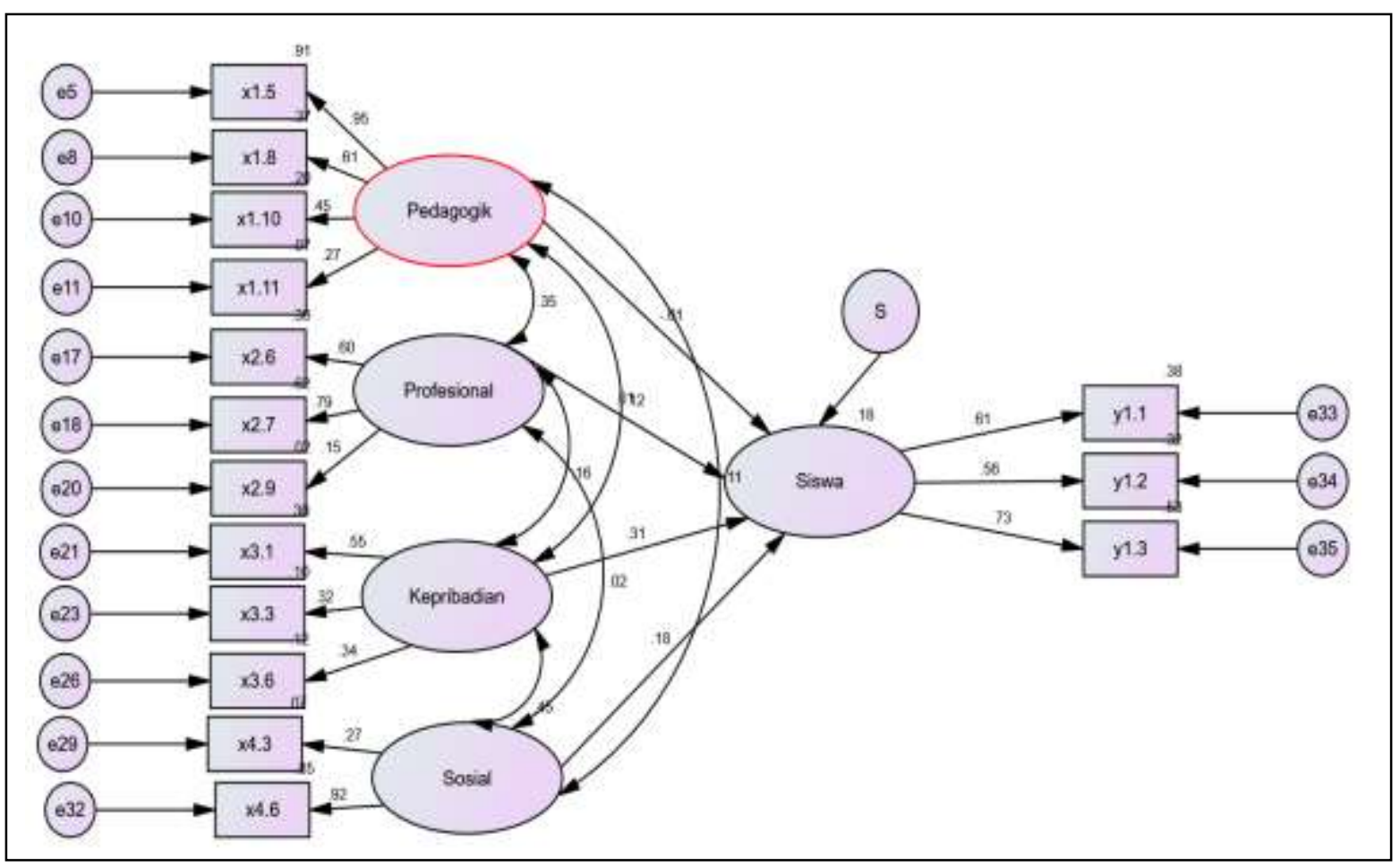

Figure 1. Final Model of Mathematics Teacher Performance Based on Students' Perceptions

Based on the data analysis, it was found that the relationship between the Student Competence variables and the Pedagogic Competence, Personality Competencies, Social Competencies and Professional Competencies of Junior High School Mathematics Teachers in Labuhanbatu were as follows:

1. Structural Model

In general, the resulting structural models are:

$Y=0,422 \times 1-0,035 \times 2-0,066 \times 3+0,403 \times 4$

Where:

$\mathrm{Y}=$ Student Competence

$x_{1}=$ Pedagogic Competence

$x_{2}=$ Professional Competence

$x_{3}=$ Personality Competencies

$x_{4}=$ Social Competence

Based on Equation (1), it appears that the regression coefficient of the relationship between Student Competence and Pedagogic Competence and Social Competence is positive, while the other two variables are negative. This indicates that the increase in student competence is influenced by each competence with the pedagogic competence and professional competence of mathematics teachers having a greater specification of student competence, so that the pedagogic competence and professional competence of teachers are the variables that most influence student competence. 
2. Relationship between Latent Variables and Indicators

In particular, the relationship between the exogenous latent variables and their respective indicators is presented in Table 1, which shows that the respective exogenous latent variable regression weight coefficients with their respective indicators. For example, in the pedagogic competency variable, the regression weight coefficient for indicator $\mathrm{x} 1.5$ is the largest and indicator $\mathrm{x} 1.11$ is the smallest. The resulting value indicates that according to students, the teacher has conveyed the core competencies, basic competencies and indicators briefly and clearly at the beginning of the lesson very well, while to improve student competence, in the pedagogic competency variable, the teacher needs to pay attention to the suitability of the material, assignments and exams with those given during learning.

Table 1. Estimated Regression Weighted Value of Endogenous and Exogenous Variables for each Indicator

\begin{tabular}{|c|c|c|}
\hline & & Estimate \\
\hline Students & <--- Pedagogic & -007 \\
\hline Students & <--- Professional & .011 \\
\hline Students & <--- Personality & .307 \\
\hline Students & $<---$ Social & .183 \\
\hline $\mathrm{x} 1.5$ & $<---$ Pedagogic & .952 \\
\hline $\mathrm{x} 4.3$ & <--- Social & .273 \\
\hline $\mathrm{x} 1.8$ & <--- Pedagogic & .611 \\
\hline $\mathrm{x} 1.10$ & <--- Pedagogic & .449 \\
\hline $\mathrm{x} 1.11$ & $<---$ Pedagogic & .271 \\
\hline$\times 2.6$ & <--- Professional & .602 \\
\hline $\mathrm{x} 2.7$ & $<---$ Professional & .790 \\
\hline $\mathrm{x} 2.9$ & <--- Professional & .147 \\
\hline $\mathrm{x} 3.3$ & <--- Personality & .322 \\
\hline $\mathrm{x} 3.1$ & $<---$ Personality & .547 \\
\hline x3.6 & <--- Personality & .340 \\
\hline $\mathrm{x} 4.6$ & <--- Social & .923 \\
\hline $\mathrm{y} 1.3$ & $<---$ Students & .731 \\
\hline $\mathrm{y} 1.2$ & $<---$ Students & .564 \\
\hline $\mathrm{y} 1.1$ & $<---$ Students & .614 \\
\hline
\end{tabular}

These results indicate that students are very dependent on the knowledge of the learning material delivered by the teacher. Therefore, it is important for teachers to focus on the lesson plans (RPP) that have been prepared previously (Sianturi, Chiang, \& Hurit, 2018).

In the professional competency variable, the regression weight coefficient for indicator x 2.7 is the largest and indicator x 2.9 is the smallest. These results explain that according to students, the teacher's ability to explain the relationship between the areas being taught and the context of life, while to improve student competence, on the professional competency variable, the teacher needs to pay attention to the relationship between the topic of discussion and daily life to make it easier for students to apply the knowledge has been obtained. 
In the Personality competency variable, the regression weight coefficient of indicator $\mathrm{x} 3.1$ is the largest and indicator $\mathrm{x} 3.3$ is the smallest. These results indicate that according to students, the teacher's confidence in teaching is very good. However, according to students, teachers should pay attention to wisdom in making decisions and treating students fairly.

In the social competency variable, only the $\mathrm{x} 4.6$ indicator has significance for student competence, thus it can be said that the teacher treats students fairly, the teacher is expected to increase social competence by getting to know students, being able to accept criticism, tolerating student diversity, increasing willingness to spend time to conduct consultations outside the classroom because sometimes students do not quite understand what has been learned in the classroom or it may be that students feel embarrassed and afraid to ask questions when the learning takes place.

Finally, the student competency variable, the regression weight coefficient of indicator y1.3 is the largest and indicator y1.2 is the smallest. These results indicate that the student's ability to explain to friends about what the teacher teaches is very good. However, students pay less attention when the teacher explains in class and are less active in asking questions in class, so to improve student competence they must pay attention to these things.

Based on the explanation above, students' perceptions of mathematics teacher performance are quite good. This is very important because the results of the data can show the value of teacher teaching performance based on the perceptions of their students. From students' perceptions, teachers are expected to continue to improve social competence and personality competence to improve student competence.

\section{Conclusion}

Based on the research conducted by the author on the performance of mathematics teachers based on student perceptions, it can be concluded that Pedagogic Competence has an important role in increasing student competence, so that if pedagogical competence decreases it will have a negative impact on student competence, while for social competence, teacher professional competence, and personality competence teachers have a positive effect on student competence. So the material indicators, assignments and exams given are in accordance with the core competencies and predetermined indicators are the most influential on the Pedagogic competency variables. The indicator of the ability to explain the relationship between the topic of discussion and the life index is the highest in professional competence.

\section{References}

Afriansyah, H. (2019). Administrasi hubungan sekolah dengan masyarakat.

Idzhar, A. (2016). Peranan guru dalam meningkatkan motivasi belajar siswa. Jurnal office, 2(2), 221-228.

Fadhli, M. (2017). Manajemen peningkatan mutu pendidikan. Tadbir: Jurnal Studi Manajemen Pendidikan, 1(2), 215-240

Ampadu, E. (2012). Students' Perceptions of their Teachers' Teaching of Mathematics: The Case of Ghana, International Online Journal of Educational Sciences, 4(2), 351358. 
Bashir, H., Alias, M., Moh, K., \& Halizah, A. (2017). Students Perceptions of Their Teachers' Performance in Teaching Engineering Drawing in Nigerian Tertiary Institutions, 3(10), 3001-3012.

Brok, P. Den, Brekelmans, M., \& Wubbels, T. (2006). Multilevel issues in research using students 'perceptions of learning environments : The case of the Questionnaire on Teacher Interaction. Learning Enviro Res, (2006), 199-213.

Danim, S. (2010). Profesionalisme dan Etika Profesi Guru. Bandung: Alfabeta.

Etuk, E. N., Afangideh, M. E., \& Uya, A. O. (2013). Students 'Perception of Teachers ' Characteristics and Their Attitude towards Mathematics in Oron Education Zone , Nigeria, 6(2), 197-204.

Hattie, J. (2003). Teachers Make a Difference, What is the research evidence? Indonesia, R. (2017). Peraturan Pemerintah Republik Indonesia Nomor 19 TentangPerubahan atas Peraturan Pemerintah Nomor 74 Tahun 2008 Tentang Guru.

Kyriakides, L., Christoforou, C., \& Charalambous, C. Y. (2013). What matters for student learning outcomes : A meta-analysis of studies exploring factors of effective teaching. Teaching and Teacher Education, 36, 143-152.

Nuryovi, Wiharna, O., \& Sriyono. (2017). Persepsi siswa tentang kompetensi pedagogik dan kompetensi kepribadian guru. Journal of Mechanical Engineering Education, 4(2), 219-224.

Palobo, M., \& Nur'aini, K. D. (2018). Pengembangan Perangkat Pembelajaran Berbasis Problem Based Learning Berorientasi pada Pengingkatan Kemampuan Penalaran dan Sikap Siswa Terhadap Matematika, Magistra, 5, 15-29.

Palobo, M., Sianturi, M., Marlissa, I., Purwanty, R., Dadi, O., \& Saparuddin, A. (2018). Analysis of Teachers' Difficulties on Developing Curriculum 2013 Lesson Plans, 226 (Icss), 1319-1324.

Rowe, K., \& Rowe, K. (2003). The Importance of Teacher Quality As A Key Determinant of Students' Experiences and Outcomes of Schooling students' experiences and outcomes of schooling

Sianturi, M., Chiang, C., \& Hurit, A. A. (2018). Impact of a Place-Based Education Curriculum on Indigenous Teacher and Students, International Journal of education, 11(1), 311-328.

Sianturi, M., \& Lin, H. H. (2016). Effects of Student's Grade to Teacher's Teaching: a Case Study in an Indigenous Classroom. Journal of Education and Vocational Research, 7(4), 6-11.

Tanujaya, B. (2016). Development of an Instrument to Measure Higher Order Thinking Skills in Senior High School Mathematics Instruction, Journal of Education and Practice, 7 (21), 144 - 148.

Tarmiji, Basyah, M. N., \& Yunus, M. (2016). Persepsi Siswa Terhadap Kesiapan Guru dalam Proses Pembelajaran. Jurnal Ilmiah Mahasiswa Pendidikan Kewarganegaraan Unsyiah, 1(1), 41-48 